\title{
Phylogenetic Relationships of Xylella fastidiosa Strains Isolated from Landscape Ornamentals in Southern California
}

\author{
Rufina Hernandez-Martinez, Karla A. de la Cerda, Heather S. Costa, Donald A. Cooksey, and Francis P. Wong
}

First, second, fourth, and fifth authors: Department of Plant Pathology, and third author: Department of Entomology, University of California, Riverside 92521.

Accepted for publication 13 February 2007.

\begin{abstract}
Hernandez-Martinez, R., de la Cerda, K. A., Costa, H. S., Cooksey, D. A., and Wong, F. P. 2007. Phylogenetic relationships of Xylella fastidiosa strains isolated from ornamentals in southern California. Phytopathology 97:857-864.

Xylella fastidiosa is an insect-borne, xylem-limited pathogenic bacterium that has been associated with a rise in incidence of diseased landscape ornamentals in southern California. The objective of this study was to genetically characterize strains isolated from ornamental hosts to understand their distribution and identity. Strains of $X$. fastidiosa isolated from ornamentals were characterized using a multiprimer polymerase chain reaction (PCR) system, random amplified polymorphic DNA

members of $X$. fastidiosa subsp. sandyi and caused oleander leaf scorch but not Pierce's disease symptoms in glasshouse assays on oleander and grape, respectively. This demonstrated both that our groupings based on genetic characterization were valid and that strains of $X$. fastidiosa subsp. sandyi are present in hosts other than oleander. Strains isolated from Spanish broom, cherry, and one strain isolated from western redbud clustered with $X$. fastidiosa subsp. fastidiosa members. Strains isolated from purple-leafed plum, olive, peach, plum, sweetgum, maidenhair tree, crape myrtle, and another western redbud strain clustered with members of $X$. fastidiosa subsp. multiplex. All strains isolated from mulberry and one from heavenly bamboo formed a separate cluster that has not yet been defined as a subspecies.
\end{abstract} (RAPD)-PCR, and sequence analysis of the 16S-23S rDNA intergenic spacer region (ISR). Based on RAPD-PCR and 16S-23S rDNA ISR, strains isolated from daylily, jacaranda, and magnolia clustered with
Additional keywords: glassy-winged sharpshooter.
Xylella fastidiosa (53) is a bacterial pathogen that causes leaf scorch in almond (40), oleander (44), sycamore (47), mulberry (34), red maple (48), elm, and oak (24), as well as Pierce's disease (PD) in grape (17), alfalfa dwarf (22), phony peach, and plum scald (54). X. fastidiosa also can infect a broad range of alternative hosts without causing visible symptoms of the disease $(16,43)$. The pathogen is xylem limited and, although graft transmissible (38), the primary manner of pathogen spread is from vector transmission $(42,52)$. The most important vectors of $X$. fastidiosa are members of the leafhopper subfamily Cicadellinae (sharpshooters) and the spittlebug family Cercopidae. These vectors have very extensive host ranges, as does the bacterium (42).

All strains of $X$. fastidiosa are classified into a single species (53); however, among members of the species, there are both genetic and phenotypic differences $(2,7,8,14,25,37,45,46)$ that might be related to host-specificity $(25,45)$; however, the classification at the level of subspecies or pathotype is not yet clear. To elucidate relationships of $X$. fastidiosa strains, many molecular techniques have been used. Among the most common techniques are randomly amplified polymorphic DNA (RAPD)-polymerase chain reaction $(\mathrm{PCR})(1,2,10,13,25)$ and sequence analysis of the $16 \mathrm{~S}-23 \mathrm{~S}$ rDNA intergenic spacer region (ISR) (9,11,37). An excellent association among RAPD clusters and pathogenicity groups of $X$. fastidiosa has been demonstrated $(1,10,13)$. On the other hand, analysis of the 16S-23S rDNA ISR also has been used widely for the genetic characterization of $X$. fastidiosa $(12,37,45)$. Using this system, three subspecies already have been described

Corresponding author: F. P. Wong; E-mail address: frank.wong@ucr.edu

doi:10.1094/PHYTO-97-7-0857

(C) 2007 The American Phytopathological Society
(45). X. fastidiosa subsp. fastidiosa includes strains isolated from cultivated grape (Vitis vinifera), alfalfa (Medicago sativa L.), maple (Acer spp.), and almond (Prunus dulcis). X. fastidiosa subsp. multiplex includes strains isolated from peach ( $P$. persica), elm (Ulmus spp.), plum (P. salicina), pigeon grape (V. aestivalis), almond, sycamore (Platanus occidentalis), and other shade trees. $X$. fastidiosa subsp. pauca includes strains isolated from citrus (Citrus sinensis) (45) and most likely coffee (Coffea arabica), given that strains isolated from the two hosts are closely related (20). There is also a suggestion for a subspecies sandyi, which includes strains isolated from oleander (Nerium oleander) (46). Although additional work is needed to validate the designation of these strains as a distinct subspecies (45), for convenience, in this work, we will refer to oleander leaf scorch strains as $X$. fastidiosa subsp. sandyi.

More than 100 plant species have been reported as hosts of $X$. fastidiosa and, with strains from new hosts still being discovered, the complete host range might be much greater than originally thought (31). The host range of the known $X$. fastidiosa strains is varied; although some strains appear to be restricted to one or a few hosts, others can multiply in several (31). For example, strains isolated from grape appear to have a broad host range; they can multiply without causing symptoms in mugwort (Artemisia absinthium), watergrass (Echinochloa crus-galli), and blackberry (Rubus discolor) (30), and they can produce diseases in almond, alfalfa, and grape (31). Also, two genetically distinct strains of the bacterium can produce similar symptoms in almond $(2,8)$. The pathotypes of the known strains have not been fully characterized, and only a limited number of reciprocal transmission tests have been conducted.

In southern California, the rate of X. fastidiosa-infected plants has increased due to the emergence and spread of an introduced vector, the glassy-winged sharpshooter (GWSS), Homalodisca 
coagulata (5). The vector has changed the epidemiology of diseases caused by $X$. fastidiosa, because it feeds on a large range of plant species, including plants of agronomic, horticultural, and ornamental importance, as well as both weeds and native plants (5). In recent work (28), X. fastidiosa strains isolated from sweetgum (Liquidambar styraciflua), purple-leafed plum (Prunus cerasifera), and olive (Olea europea) were characterized. The objective of this study was to establish the genetic relationships among $X$. fastidiosa strains isolated from these ornamentals with previously characterized strains to ascertain the identity of the landscape ornamental strains and potential for landscape ornamentals to serve as inoculum reservoirs for strains that threaten economically important hosts such as grape and almond. In this work, strains isolated from different ornamental hosts in southern California, including mulberry (Morus alba), daylily (Hemerocallis spp.), sweetgum, jacaranda (Jacaranda mimosifolia), western redbud (Cercis occidentalis), magnolia (Magnolia grandiflora), maidenhair tree (Ginkgo biloba), heavenly bamboo (Nandina domestica), Spanish broom (Spartium junceum), purple-leafed plum, olive, and crape myrtle (Lagerstroemia indica) were characterized using three methods: multiprimer PCR, 16S-23S rDNA ISR sequencing, and RAPD-PCR DNA analyses. We present data showing the diversity and relationship of $X$. fastidiosa in landscape hosts and show the utility of these methods in the phylogenetic analysis of the pathogen.

\section{MATERIALS AND METHODS}

Collection of samples and bacterial isolation. In 2003 and 2004, a survey was initiated to examine landscape and ornamental hosts of $X$. fastidiosa in southern California. The methodology was described previously by Hernandez-Martinez et al. (29). Briefly, five urban locations with multiple landscape hosts showing X. fastidiosa-like symptoms were surveyed: Fillmore (Ventura County), Redlands (San Bernardino County), Riverside (Riverside County), San Diego (San Diego County), and Tustin (Orange County). Samples were tested for the presence of $X$. fastidiosa with enzyme-linked immunosorbent assay (ELISA) using the PathoScreen Kit (Agdia Inc. Elkhart, IN). Isolations were made using both PD3 (18) and PW (19) media in 6-cmdiameter sterile petri dishes (Fisher Scientific, Pittsburgh, PA), substituting agar with $0.8 \%$ gelrite (Sigma-Aldrich, St. Louis) in both media types. Samples were prepared as described by Costa et al. (16). Plates were incubated at $28^{\circ} \mathrm{C}$ and inspected for colony growth 1,2, and 6 weeks after extraction. Suspected colonies of $X$. fastidiosa were subcultured on new PD3 and PW media for PCR identification using the RST31 and RST33 primer pair (39). Strains from which the 733-bp product was amplified were considered $X$. fastidiosa positive. Individual colonies then were transferred to fresh PW and PD3 medium plates and maintained with regular transfers on fresh media for the duration of the study. Cultures also were placed in PW broth with $20 \%$ glycerol at $-80^{\circ} \mathrm{C}$ for long-term storage.

DNA extraction and PCR amplification. The strains used in this study are described in Table 1. Genomic DNA was extracted from all the strains, except for Mulberry-VA, CI.11067, CI.52, and PE.PLS, from which the 16S-23S ISR sequence data (GenBank accession nos. AY196794, AF237650, AF203393, and AF203396, respectively) was used. For genomic DNA extraction, individual strains were grown in petri dishes containing $25 \mathrm{ml}$ of PD3 or PW broth and allowed to grow at $28^{\circ} \mathrm{C}$ without shaking. After 15 days, bacterial cells were recovered by transferring the cell suspension to a 40-ml Sartedt polypropylene tube (Sartedt, Nümbracht, Germany) and centrifuging at $8,000 \mathrm{rpm}$ in a Beckman J2-21M centrifuge. From the recovered pellet, DNA was extracted with the Qiagen DNA tissue kit (Qiagen Inc., Valencia, CA) and adjusted with Tris-EDTA to a final concentration of $50 \mathrm{ng} / \mu \mathrm{l}$.
Characterization of $X$. fastidiosa strains using multiprimer PCR. A recently developed multiprimer PCR system (27), which employs three primer sets, was used as part of the characterization of the collected strains. Briefly, multiprimer PCR reactions were carried out with a mixture of six primers at 25 pmol each. Primers used were XF1968-L (5'-GGAGGTTTACCGAAGACAGAT-3'), XF1968-R (5'-ATCCACAGTAAAACCACATGC-3'), XF2542-L (5'-TTGATCGAGCTGATGATCG-3'), XF2542-R (5'-CAGTACAGCCTGCTGGAGTTA-3'), ALM1 (5'-CTGCAGAAATTGGAAACTTCAG-3'), and ALM2 (5'-GCCACACGTGATCTATGAA$\left.3^{\prime}\right)$. PCR amplification was performed in a $25-\mu l$ reaction volume containing $10 \times$ PCR buffer, $2.5 \mathrm{mM}$ of $\mathrm{MgCl}_{2}$, dNTP mix at $200 \mu \mathrm{M}$ each, $25 \mathrm{pmol}$ of each primer, $50 \mathrm{ng}$ of genomic DNA, and 2.5 units of Taq DNA polymerase (Promega Corp. Madison, WI). Amplification was done in a thermal cycler (PTC-200 Peltier) programmed for $5 \mathrm{~min}$ at $94^{\circ} \mathrm{C}$, followed by 40 cycles of $94^{\circ} \mathrm{C}$ for $1 \mathrm{~min}, 55^{\circ} \mathrm{C}$ for $1 \mathrm{~min}$, and $72^{\circ} \mathrm{C}$ for $1 \mathrm{~min}$. After the final cycle, an additional extension step was performed at $72^{\circ} \mathrm{C}$ for $10 \mathrm{~min}$. Products were analyzed by electrophoresis using a $1.5 \%$ agarose gel run in Tris-borate-EDTA (88.9 mM Tris, $8.9 \mathrm{mM}$ boric acid, and $2.5 \mathrm{mM}$ EDTA) and stained with ethidium bromide at $0.5 \mu \mathrm{g} / \mathrm{ml}$ to visualize the products.

Characterization of $X$. fastidiosa strains by analysis of the 16S-23S ISR region. The ISR sequences of all $X$. fastidiosa strains described in Table 1 were PCR amplified using the primer pair G1 (5'-GAAGTCGTAACAAGG-3') and L1 (5'-CAAGGCATCCACCGT-3'). Amplification was done as described previously (25). The PCR-amplified products were electrophoresed, and the excised bands of $\approx 520$ bp purified using QIAquick Gel Extraction Kit (Qiagen Inc.) following the manufacturer's instructions. Purified fragments were cloned into pGEM-T Easy Vector Systems (Promega Corp.), and the cloned fragments were sequenced. The 16S-23S rDNA ISR sequences were aligned using the default values of the multiple alignment parameters of the ClustalX (version 1.83) program (51) and their relatedness was determined by neighbor-joining analysis and maximum parsimony analysis using the MEGA version 3.1 package (35). Performing 1,000 bootstraps assessed the reproducibility of the resulting tree. The phylogenetic tree then was displayed with the TreeView program (version 1.4, University of Glasgow, Glasgow, UK) (41).

Characterization of $X$. fastidiosa strains by RAPD-PCR analysis. A RAPD-PCR analysis was performed as described before (25), using 10-base primers (Kit AA; Operon Technologies, Inc., Alameda, CA). Primers used were OP-AA-06 (5'-GTGGGTGCCA-3'), OP-AA-04 (5'-AGGACTGCTC-3'), OP-AA-09 (5'-AGATGGGCAG-3'), OP-AA-02 (5'-GAGACCAGAC-3'), OP-AA-03 (5'-TTAGCGCCCC-3'), and OP-AA-11 (5'-ACCCGACCTG-3'). For amplification, Ready-to-go PCR beads (Amersham Pharmacia Biotech Inc, Piscataway, NJ) were used (final concentration: $10 \mathrm{mM}$ Tris- $\mathrm{HCl}, 50 \mathrm{mM} \mathrm{KCl}, 1.5 \mathrm{mM}$ $\mathrm{MgCl}_{2}$, dNTP mix at $200 \mu \mathrm{M}$ each, and 3 units of Taq DNA polymerase). Each reaction contained one Ready-to-go PCR bead, $50 \mathrm{ng}$ of genomic DNA, $25 \mathrm{pmol}$ of a single primer, and water to obtain a final volume of $25 \mu \mathrm{l}$. Amplification was done in a thermal cycler, programmed for $95^{\circ} \mathrm{C}$ for $3 \mathrm{~min}$; followed by 45 cycles of $94^{\circ} \mathrm{C}$ for $1 \mathrm{~min}, 35^{\circ} \mathrm{C}$ for $1 \mathrm{~min}$, and $72^{\circ} \mathrm{C}$ for $2 \mathrm{~min}$; with a final extension of $72^{\circ} \mathrm{C}$ for $10 \mathrm{~min}$; samples then were held at $4^{\circ} \mathrm{C}$. For consistency and reproducibility, each primer was used in two independent PCR reactions. Photographs from ethidiumbromide-stained agarose gels were used to score RAPD data for analysis. Each amplification band was treated as a unit character and was scored as 1 (present) or 0 (absent). Bands with the same mobility were treated as identical fragments. Data analyses were performed using PAUP* 4.0b2a software (50) by creating the most parsimony tree. The strength of the tree topology was assessed by bootstrapping 1,000 times and the tree displayed with the TreeView program (41). 
Mechanical inoculation of strains isolated from magnolia, daylily, and jacaranda into grape and oleander plants. Using the aforementioned methods, strains from magnolia, jacaranda, and daylily were identified as being similar to X. fastidiosa subsp. sandyi. This subspecies was never reported as having hosts other than oleander (44). To test the hypothesis that these strains would infect oleander, they were mechanically inoculated to oleander and grape plants as described by Hernandez-Martinez et al. (29). Briefly, young rooted cuttings of oleander obtained from a commercial nursery in 5-by-5-by-20-cm containers and 2-monthold rooted cuttings of grape var. Pinot Noir (University of
California Foundation Plant and Materials Service, Davis) were grown. All plants were pretested using ELISA as described above, to ensure that they were free of $X$. fastidiosa before use. Plants were potted in 3.8-liter plastic pots filled with University of California soil mix, watered four times a week as needed, and maintained in glasshouses at ambient environmental conditions $\left(\approx 20\right.$ to $\left.30^{\circ} \mathrm{C}\right)$ for the duration of the experiment. Strains used were HEM034, isolated from daylily; JM028, isolated from jacaranda; MG028, isolated from magnolia; A05, a X. fastidiosa subsp. fastidiosa strain confirmed as causing PD (29); and Riverside3, an $X$. fastidiosa subsp. sandyi strain known to cause

TABLE 1. Strains used in this study and their host sources

\begin{tabular}{|c|c|c|c|c|}
\hline Host scientific name & Host common name & Isolate designation $^{\mathrm{a}}$ & $\begin{array}{l}\text { County of California or state } \\
\text { from which strain was isolated }\end{array}$ & Reference or source \\
\hline Cercis occidentalis & Western redbud & cercis 050 & Riverside & This study \\
\hline C. occidentalis & Western redbud & cercis049 & Riverside & This study \\
\hline Citrus sinensis & Citrus & CI.11067* & Sao Paulo, Brazil & Mehta and Rosato (37) \\
\hline C. sinensis & Citrus & CI.52* & Sao Paulo, Brazil & Mehta and Rosato (37) \\
\hline Ginkgo biloba & Maidenhair tree & GB100 & Riverside & This study \\
\hline Hemerocallis spp. & Daylily & HEM034 & Riverside & This study \\
\hline Jacaranda mimosifolia & Jacaranda & JM028 & Riverside & This study \\
\hline Lagerstroemia indica & Crape myrtle & LI021 & San Bernardino & This study \\
\hline Liquidambar styraciflua & Sweetgum & LS020 & San Bernadino & This study \\
\hline L. styraciflua & Sweetgum & LS022 & San Bernadino & This study \\
\hline L. styraciflua & Sweetgum & LS043 & San Bernadino & This study \\
\hline Magnolia grandiflora & Magnolia & MG038 & San Bernadino & This study \\
\hline Morus alba & White mulberry & MLS063 & San Bernardino & Hernandez-Martinez et al. (28) \\
\hline M. alba & White mulberry & MLS059 & San Bernardino & Hernandez-Martinez et al. (28) \\
\hline M. alba & White mulberry & MLS012 & San Bernadino & Hernandez-Martinez et al. (28) \\
\hline M. alba & White mulberry & MLS024 & Riverside & Hernandez-Martinez et al. (28) \\
\hline M. alba & White mulberry & Mulberry-VA* & Virginia & Huang and Sherald (32) \\
\hline Nandina domestica & Heavenly bamboo & NI065 & San Bernardino & This study \\
\hline Nerium oleander & Oleander & OLS012 & Riverside & This study \\
\hline N. oleander & Oleander & OLS028 & Riverside & This study \\
\hline N. oleander & Oleander & Ann1 & Palm Springs & Hendson et al. (25) \\
\hline N. oleander & Oleander & TR2 & Orange & A. Purcell, personal gift \\
\hline N. oleander & Oleander & Riverside 3 & Riverside & Hernandez-Martinez et al. (28) \\
\hline Olea europaea & Olive & G12 & Riverside & This study \\
\hline Prunus cerasifera & Purple leafed-plum & PC057 & Riverside & This study \\
\hline$P$. cerasifera & Purple leafed-plum & PC086 & Riverside & This study \\
\hline P. cerasifera & Purple leafed-plum & PC045 & Riverside & This study \\
\hline P. cerasifera & Purple leafed-plum & PC052 & Riverside & This study \\
\hline P. cerasifera & Purple leafed-plum & PC053 & Riverside & This study \\
\hline P. cerasifera & Purple leafed-plum & PC076 & San Bernardino & This study \\
\hline P. cerasifera & Purple leafed-plum & PCAcl12 & Riverside & This study \\
\hline P. domestica & Plum & Plum 2\#4 & Georgia & Hendson et al. (25) \\
\hline P. dulcis & Almond & ALS2 & San Joaquin & Hendson et al. (25) \\
\hline P. dulcis & Almond & ALS1 & San Joaquin & Hendson et al. (25) \\
\hline P. dulcis & Almond & Tulare-ALS & Tulare & Hendson et al. (25) \\
\hline P. dulcis & Almond & Fresno & Fresno & Almeida and Purcell (2) \\
\hline P. dulcis & Almond & ALS6 & San Joaquin & Hendson et al. (25) \\
\hline P. dulcis & Almond & 276 & Temecula & Costa et al. (15) \\
\hline P. dulcis & Almond & Dixon & Solano & Hendson et al. (25) \\
\hline P. dulcis & Almond & Butte & Butte & Hendson et al. (25) \\
\hline P. dulcis & Almond & Glenn & Glenn & Almeida and Purcell (2) \\
\hline P. dulcis & Almond & ALS035 & San Bernardino & This study \\
\hline P. dulcis & Almond & ALS036 & San Bernardino & This study \\
\hline P. avium & Cherry & cherry018 & San Bernardino & This study \\
\hline P. avium & Cherry & cherry019 & San Bernardino & This study \\
\hline P. persica & Peach & $5 \mathrm{R} 1$ & Georgia & Hendson et al. (25) \\
\hline Pyrus pyrifolia & Pear & PE.PLS* & Taiwan & Mehta and Rosato (37) \\
\hline Quercus sp. & Oak & $92-10$ & Florida & This study \\
\hline Quercus sp. & Oak & $92-3$ & Florida & Hendson et al. (25) \\
\hline Spartium junceum & Spanish broom & N10 & Temecula & Costa et al. (15) \\
\hline S. junceum & Spanish broom & SB-R & Riverside & This study \\
\hline Unknown & Bush & UK005 & Riverside & This study \\
\hline Vitis vinifera & Grape & $95-2$ & Florida & Hendson et al. (25) \\
\hline$V$. vinifera & Grape & SJV1 & Florida & A. Purcell \\
\hline V. vinifera & Grape & Florida & Florida & This study \\
\hline$V$. vinifera & Grape & STL & Napa & Hendson et al. (25) \\
\hline$V$. vinifera & Grape & Preston Ranch & Sonoma & Hendson et al. (25) \\
\hline$V$. vinifera & Grape & A05 & Temecula & Hendson et al. (25) \\
\hline
\end{tabular}

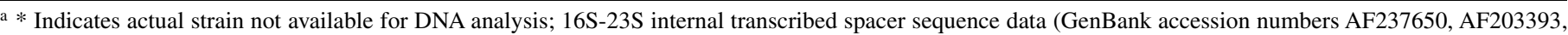
AY196794, and AF203396, respectively) were used for comparative analysis. 
oleander leaf scorch (29). Inoculation was performed as previously described by Hernandez-Martinez et al. (29). Briefly, strains were grown on PW medium (19) for 5 days. Harvested bacteria were resuspended to a turbid suspension $\left(10^{7}\right.$ to $\left.10^{8} \mathrm{CFU}\right)$ in $\mathrm{pH} 7$ phosphate-buffered saline (PBS) solution. Plants were inoculated by pipetting a small drop of the bacterial suspension onto a stem and probing with a \#1 insect pin until the drop was absorbed. Each strain was inoculated on 15 oleander and 10 grape plants.

TABLE 2. Characterization of strains based on multiprimer polymerase chain reaction (PCR) analysis

\begin{tabular}{|c|c|c|c|c|}
\hline \multirow[b]{2}{*}{ Strain } & \multicolumn{3}{|c|}{ PCR results using primer set ${ }^{\mathrm{a}}$} & \multirow[b]{2}{*}{ Subspecies/strain ${ }^{b}$} \\
\hline & XF1968 & ALM & XF2542 & \\
\hline $95-2$ & - & - & + & fastidiosa/PD \\
\hline ALS035 & - & - & + & fastidiosa/PD \\
\hline ALS036 & - & - & + & fastidiosa/PD \\
\hline ALS1 & - & - & + & fastidiosa/PD \\
\hline cercis 050 & - & - & + & fastidiosa/PD \\
\hline cherry018 & - & - & + & fastidiosa/PD \\
\hline cherry019 & - & - & + & fastidiosa/PD \\
\hline Florida & - & - & + & fastidiosa/PD \\
\hline Fresno & - & - & + & fastidiosa/PD \\
\hline N10 & - & - & + & fastidiosa/PD \\
\hline Preston Ranch & - & - & + & fastidiosa/PD \\
\hline SB-R & - & - & + & fastidiosa/PD \\
\hline SJV1 & - & - & + & fastidiosa/PD \\
\hline STL & - & - & + & fastidiosa/PD \\
\hline Tulare-ALS & - & - & + & fastidiosa/PD \\
\hline Ann1 & + & - & - & sandyi/OLS \\
\hline HEM034 & + & - & - & sandyi/OLS \\
\hline JM028 & + & - & - & sandyi/OLS \\
\hline MG038 & + & - & - & sandyi/OLS \\
\hline MLS012 & + & - & - & sandyi/OLS \\
\hline MLS024 & + & - & - & sandyi/OLS \\
\hline MLS059 & + & - & - & sandyi/OLS \\
\hline MLS063 & + & - & - & sandyi/OLS \\
\hline NI065 & + & - & - & sandyi/OLS \\
\hline OLS012 & + & - & - & sandyi/OLS \\
\hline OLS028 & + & - & - & sandyi/OLS \\
\hline TR2 & + & - & - & sandyi/OLS \\
\hline 276 & + & + & + & multiplex/ALSII \\
\hline $5 \mathrm{R} 1$ & + & + & + & multiplex/ALSII \\
\hline $92-10$ & + & + & + & multiplex/ALSII \\
\hline $92-3$ & + & + & + & multiplex/ALSII \\
\hline ALS6 & + & + & + & multiplex/ALSII \\
\hline Butte & + & + & + & multiplex/ALSII \\
\hline cercis049 & + & + & + & multiplex/ALSII \\
\hline G12 & + & + & + & multiplex/ALSII \\
\hline GB100 & + & + & + & multiplex/ALSII \\
\hline Glenn & + & + & + & multiplex/ALSII \\
\hline LI021 & + & + & + & multiplex/ALSII \\
\hline LS020 & + & + & + & multiplex/ALSII \\
\hline LS022 & + & + & + & multiplex/ALSII \\
\hline LS043 & + & + & + & multiplex/ALSII \\
\hline PC012 & + & + & + & multiplex/ALSII \\
\hline PC052 & + & + & + & multiplex/ALSII \\
\hline PC053 & + & + & + & multiplex/ALSII \\
\hline PC057 & + & + & + & multiplex/ALSII \\
\hline PC076 & + & + & + & multiplex/ALSII \\
\hline PC086 & + & + & + & multiplex/ALSII \\
\hline Plum2\#4 & + & + & + & multiplex/ALSII \\
\hline UK005 & + & + & + & multiplex/ALSII \\
\hline ALS2 & + & + & - & multiplex/ALSII \\
\hline Dixon & + & + & - & multiplex/ALSI \\
\hline PC045 & + & + & - & multiplex/ALSI \\
\hline
\end{tabular}

a Primers used for PCR were XF1968 (5'-GGAGGTTTACCGAAGACAGAT$3^{\prime}$ and 5'-ATCCACAGTAAAACCACATGC-3', 638-bp product), ALM (5'CTGCAGAAATTGGAAACTTCAG- $3^{\prime}$ and $5^{\prime}$-GCCACACGTGATCTATGAA-3', 521-bp product), and XF2542 (5'-TTGATCGAGCTGATGATCG-3' and 5'-CAGTACAGCCTGCTGGAGTTA-3', 412-bp product); + = product obtained by PCR and subsequent visualization by gel electrophoresis and $-=$ no product was amplified.

${ }^{\mathrm{b}}$ Subspecies/strain genotype based on multiprimer PCR, designation based upon Hernandez-Martinez et al. (27). PD = Pierce's disease, OLS = oleander leaf scorch, and ALS = almond leaf scorch.
Inoculations with PBS served only as negative controls. After 2 months, three petioles randomly chosen from each inoculated plant were tested with ELISA and the isolation from positive plants on modified PD3 medium ( $0.8 \%$ gelrite instead of agar) was performed as described by Costa et al. (16). The identity of putative $X$. fastidiosa colonies was confirmed by PCR using the methods and primers RST31 and RST33 as described above.

\section{RESULTS}

Characterization of $X$. fastidiosa strains by multiprimer PCR. The multiprimer PCR analysis revealed four groups (Table 2 ). The first included strains previously characterized as members of $X$. fastidiosa subsp. fastidiosa isolated from Spanish broom (SB10 and N10), almond (ALS035, ALS036, ALS1, Tulare, and Fresno), and grape (95-2, SJV1, Florida, STL, and Preston Ranch) $(25,27)$ as well as one of two strains isolated from western redbud (cercis050) and the strains isolated from cherry (cherry019 and cherry018). The second group included strains isolated from sweetgum (LS020, LS022, and LS043), purpleleafed plum (PC057, PC086, PC052, PC053, PC076, and PCAcl12), maidenhair tree (GB100), olive (G12), crape myrtle (LI021), oak (92-10 and 92-3), and the remaining western redbud strain (cercis049), as well as the strains isolated from peach (5R1), plum (plum2\#4), and some from almond (ALS6 and 276) that previously were characterized as $X$. fastidiosa subsp. multiplex members $(27,45)$. The third group included strains isolated from magnolia (MG038), jacaranda (JM028), daylily (HEM038), mulberry (MLS063, MLS059, MLS012, and MLS024), heavenly bamboo (NI065), and the $X$. fastidiosa subsp. sandyi strains isolated from oleander (Ann1, TR2, OLS012, and OLS028). Finally, the last group included a strain isolated from purple-leafed plum (PC045) and the almond strains Dixon and ALS2.

Characterization of $X$. fastidiosa strains by analysis of the 16S-23S rDNA ISR. The base nucleotide sequences are shown in Figure 1, and a phylogenetic tree constructed using those sequence data and the maximum parsimony analysis is shown in Figure 2. Using the neighbor-joining analysis, the phylogenetic tree produced was similar to the most parsimonious tree (data not shown). Although the analysis of the tree revealed six groupings, the strains isolated from California belonged to four of them. The first clade included the strains CI.52 and CI.11067 isolated from citrus. The second clade included the strains 92-10 and 92-3 isolated from oak. The third clade included strains isolated from purple-leafed plum (PC086, PC045, PCAcl12, PC057, PC052, PC076, and PC053), olive (G12), sweetgum (LS020, LS022, and LS043), peach (5R1), plum (Plum2\#4), western redbud (cercis049), maidenhair tree (GB100), crape myrtle (LI021), the UK005 strain, and some previously characterized as $X$. fastidiosa subsp. multiplex strains (Dixon, Butte, ALS6, ALS2, 276, and Glenn). The fourth clade included members of $X$. fastidiosa subsp. sandyi isolated from oleander (OLS028, OLS012, Ann1, and TR2) as well as the strains isolated from daylily (HEM034), magnolia (MG038), and jacaranda (JM028). The fifth clade included strains isolated from mulberry (MLS024, MLS063, MLS012, MLS059, and Mulberry-VA) and heavenly bamboo (NI065). The last clade included members of $X$. fastidiosa subsp. fastidiosa isolated from grape (Florida, STL, Preston Ranch, 925, and SJV1), almond (ALS1, Tulare, ALS035, ALS036, and Fresno), as well as the strains isolated from cherry (cherry018 and cherry019), Spanish broom (N10 and SB-R), and one from western redbud (cercis050).

Characterization of $X$. fastidiosa strains by RAPD analysis. The phylogenetic relationships based on 80 scorable RAPD characters were analyzed (Fig. 3). Analysis of the phylogenetic tree revealed six main clades. The first comprised strains isolated from oak (92-3 and 92-10). The second clade was composed of strains isolated from sweetgum (LS020, LS022, and LS043). All 
previously recognized members of $X$. fastidiosa subsp. multiplex (Dixon, Butte, ALS6, ALS2, 276, and Glenn) clustered into the third clade, as well as the strains isolated from purple-leafed plum (PC086, PC045, PCAcl12, PC057, PC052, PC076, and PC053), olive (G12), western redbud (cercis049), maidenhair tree (GB100), the UK005, crape myrtle (LI021), and plum (Plum2\#4). The fourth clade was integrated from strains isolated from mulberry (MLS024, MLS063, MLS012, and MLS059) and heavenly bamboo (NI065). The fifth clade included all the strains isolated from oleander (OLS028, OLS012, TR2, and Ann1), as well as the strains isolated from daylily (HEM034), jacaranda (JM028), and magnolia (MG038).

The peach strain (5R1) seemed to form a group apart from strains of $X$. fastidiosa subsp. fastidiosa. The last clade was formed by strains isolated from grape (92-5, Florida, STL, Preston Ranch, and SJV1), almond (ALS036, ALS035, ALS1, and Fresno), cherry (cherry019 and cherry018), Spanish broom (N10 and SB-R), and western redbud (cercis50). Except for the peach and sweetgum strains that were separate from $X$. fastidiosa subsp. multiplex, results produced by RAPD analysis were similar to those produced using 16S-23S rDNA ITS analysis.

Mechanical inoculations of selected strains into grape and oleander plants. The strains from jacaranda, magnolia, and daylily (JM028, MG038, and HM034) appeared to be members of $X$. fastidiosa subsp. sandyi based upon the multiprimer PCR, ISR, and RAPD analysis. All oleander plants inoculated with the strains Riverside3, JM028, MG038, and HM034 showed symptoms after 2 months of inoculation (Table 3). On the other hand, only the grape plants inoculated with the A05 strain developed disease symptoms. No PBS-inoculated control plants were symptomatic or gave positive ELISA or PCR reactions, and X. fastidi- osa could not be recovered from these. Symptomatic plants tested positive for $X$. fastidiosa infection with ELISA and the pathogen could be recovered from all infected plants. Colonies did not differ morphologically (light microscopy), serologically (ELISA), or by growth in modified PD3 medium from the original strains used as inoculum. The 16S-23S rDNA ISR of selected colonies were PCR amplified, cloned, sequenced, and compared as described above. The sequences were $100 \%$ identical to the strain Riverside3 used for inoculation (data not shown).

\section{DISCUSSION}

In this study, RAPD-PCR, 16S-23S rDNA ISR, and a multiprimer PCR analysis were used to assess the genetic relationships among $X$. fastidiosa strains isolated from landscape ornamentals. The RAPD-PCR analysis distinguished the highest degree of genomic diversity and the multiprimer the lowest, but the strains clustered similarly within small groups. The combination of results allowed the identification of several members of $X$. fastidiosa subsp. multiplex, X. fastidiosa subsp. fastidiosa, and X. fastidiosa subsp. sandyi $(45,46)$, as well as mulberry leaf scorch-associated strains. None of the strains isolated from ornamentals growing in California were closely related to X. fastidiosa subsp. pauca or the oak strains previously reported in the eastern of the United States $(3,4,6,23,33,36)$. As Schaad et al. (45) reported previously, some strains isolated from almond (in our case, 6 of 11), peach, and plum are members of $X$. fastidiosa subsp. multiplex. Many of the ornamental strains also appeared to belong to this subspecies based upon the rDNA sequences and RAPD analysis, including the strains isolated from olive, maidenhair tree, crape myrtle, purple-leafed plum, and one of two western redbud strains.

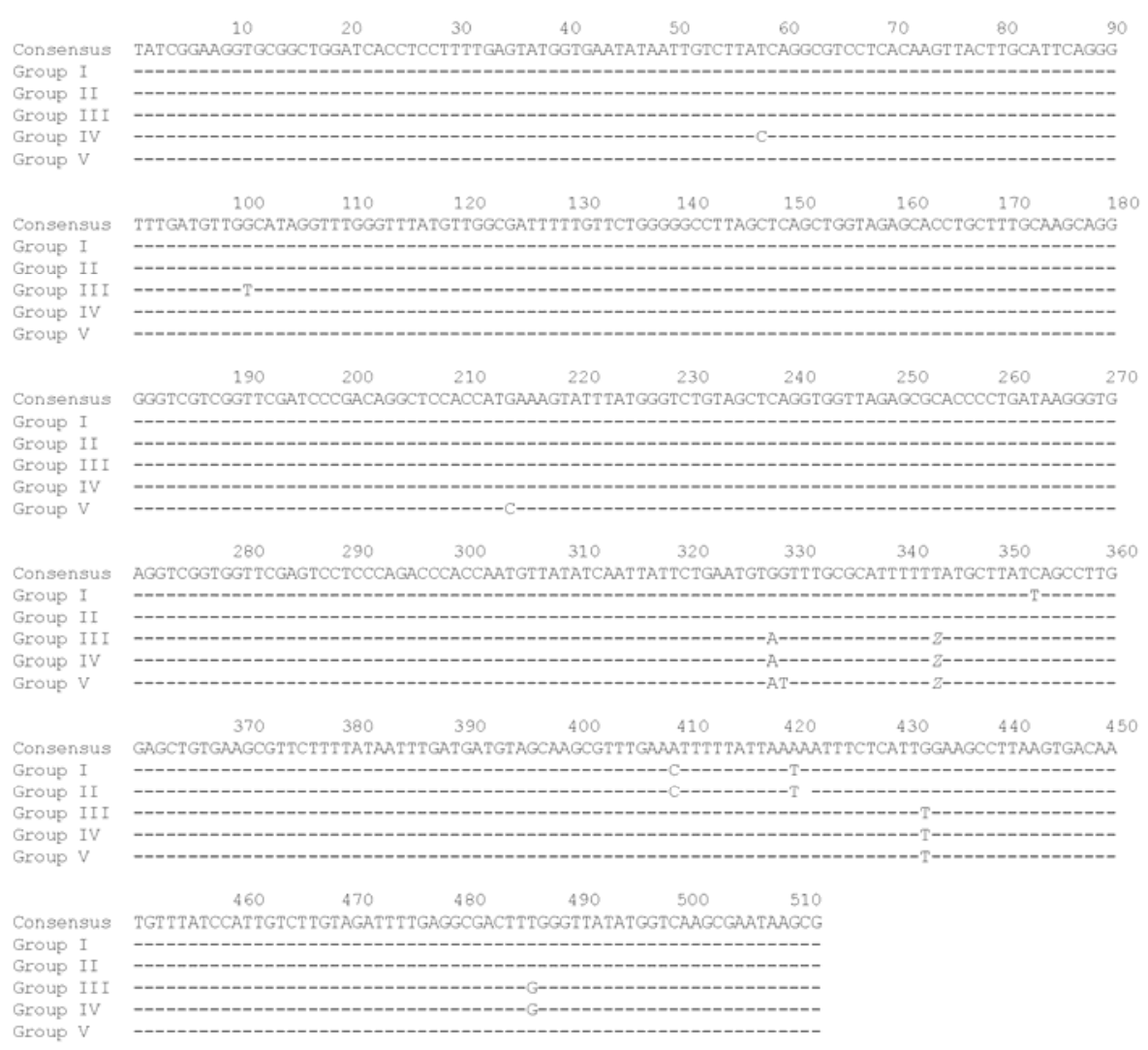

Fig. 1. Nucleotide sequences of the rDNA 16S-23S intergenic spacer region (ISR) of Xylella fastidiosa strains. The general consensus for 52 strains is shown for all bases (1 to 512). Consensus sequences representing groups I (strains 92-10 and 92-3), II (strains PC086, PC045, PCAc112, PC057, PC052, PC076, PC053, G12, Dixon, Butte, ALS6, ALS2, 276, Glenn, LS020, LS022, LS043, 5R1, Plum2\#4, cercis049, GB100 and UK005), III (strains: MLS024, MLS063, MLS012, MLS059, Mulberry-VA, and NI065), IV (strains Florida, STL, Preston Ranch, 92-5, SJV1, Fresno, ALS1, Tulare, ALS035, ALS036, cherry018, cherry019, N10, SB-R, and cercis050), and V (strains OLS028, OLS012, Ann1, TR2, HEM034, MG038, and JM028) are shown only for those bases (A, T, C, G) differing or deleted $(\mathrm{Z})$ from the general consensus. 


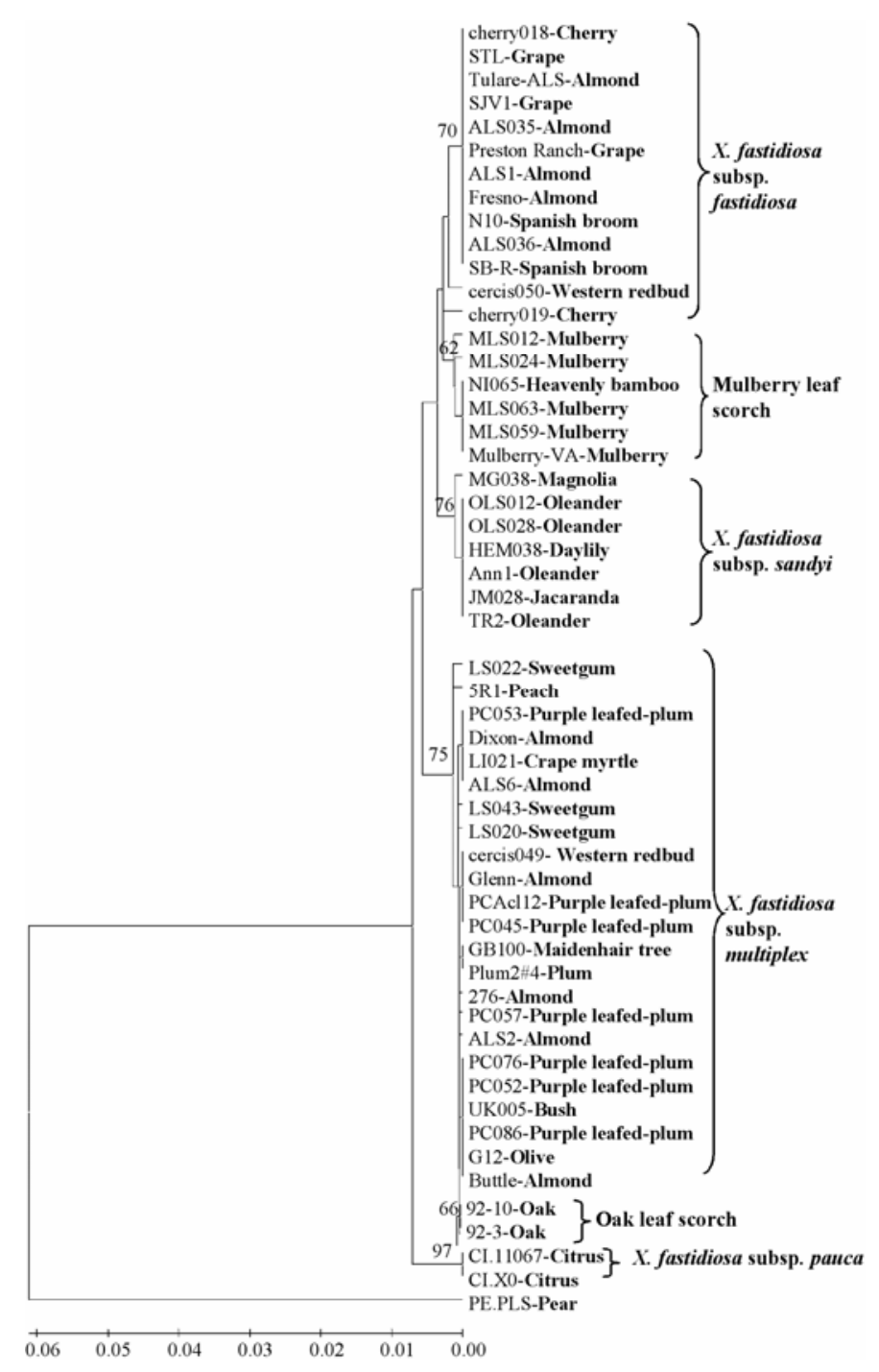

Fig. 2. Phylogenetic tree constructed using the neighbor-joining method, based on 16S-23S rDNA intergenic region sequence data for Xylella fastidiosa. The numbers above the branches represent bootstrap percentages obtained for 1,000 replicates.

For the sweetgum strains, there were some differences between 16-23S rDNA and RAPD analysis. Based upon 16-23S rDNA ISR sequences, these sweetgum strains appeared to be members of X. fastidiosa subsp. multiplex; however, RAPD analysis indicated that they form a separate group. A strain isolated from sweetgum that was mechanically inoculated into almond, grape, or oleander was unable to produce disease symptoms on those plants (26), indicating that this strain might be part of a new subspecies or pathovar and supporting the phylogenetic division described above.

Strains isolated from purple-leaf plum were similar to a plum leaf scald strain (Plum2\#4) and a phony peach strain (5R1) from Georgia based on 16-23S rDNA ISR sequence. However, the RAPD-PCR analysis separated the peach strain from the plum and purple-leaf plum strains. In previous work performed by Hendson et al (25), both plum leaf scald and phony peach strains grouped together. Although it is known that phony peach and plum leaf scald strains are cross-infective based on reciprocal transmissions by grafting (21), some strains show some genetic differences (25). Perhaps these minor genetic differences and use of only 6 random primers instead of the 20 used by Hendson (25) caused the peach isolate to group outside of the plum in our RAPD-PCR analysis. It remains unknown whether our purpleleafed plum plants in California harbor strains that are able to

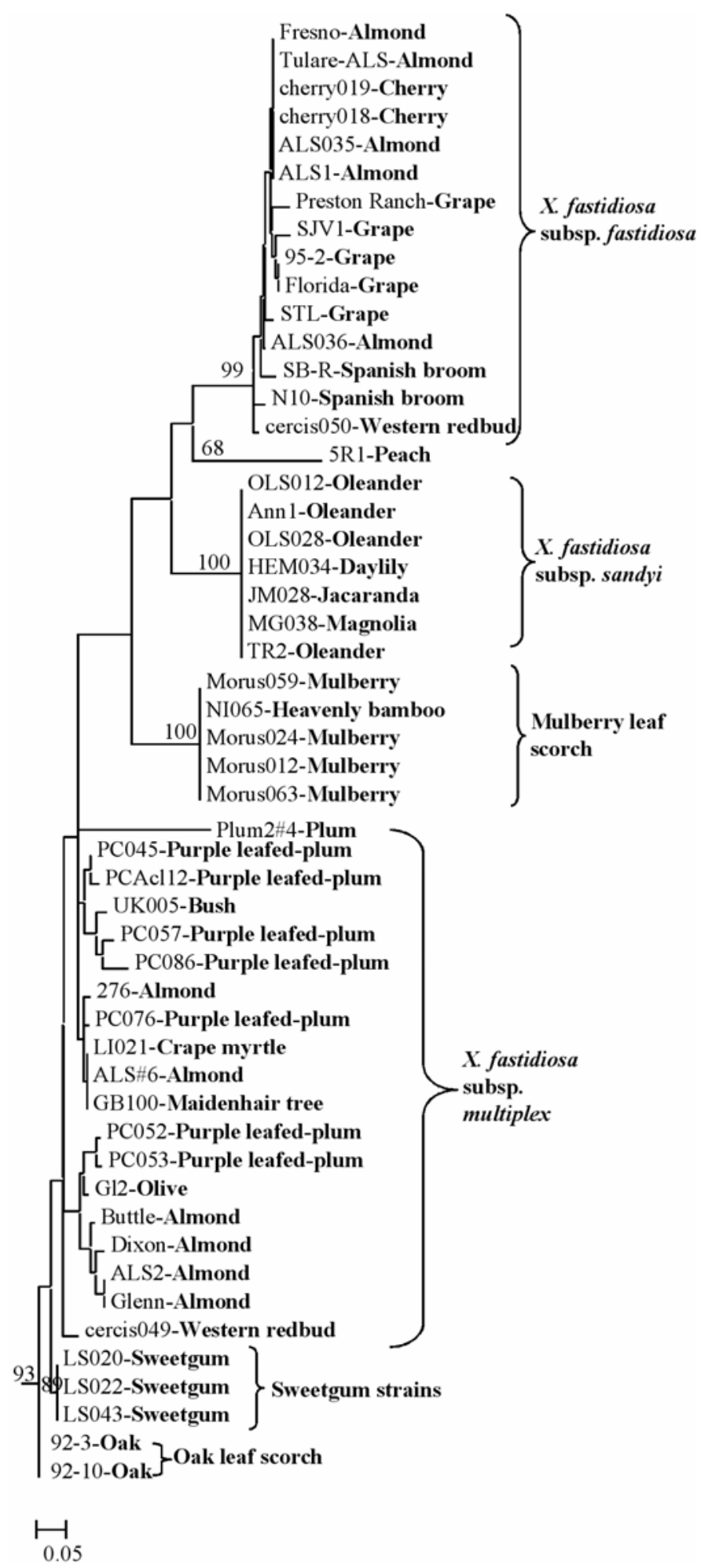

Fig. 3. Phylogenetic tree constructed using maximum parsimony analysis method, based on random amplified polymorphic DNA data for Xylella fastidiosa. The numbers above the branches represent bootstrap percentages obtained from 100 replicates.

infect plum. Analyses of a larger number of plum, purple-leafed plum, and peach strains would allow for this relationship to be better understood.

All strains isolated from grape and 5 of 11 almond strains were shown by $16-23 \mathrm{~S}$ rDNA ISR sequence and RAPD-PCR analysis to be members of $X$. fastidiosa subsp. fastidiosa. In addition, we found that one of the two western redbud strains, the Spanish broom strains, and the cherry strains characterized here belong to 
TABLE 3. Evaluation of Xylella fastidiosa strains isolated from oleander, grape, jacaranda, magnolia, and daylily for pathogenicity to grape and oleander

\begin{tabular}{|c|c|c|c|c|c|c|c|c|}
\hline \multirow[b]{2}{*}{ X. fastidiosa strain/subspecies } & \multirow[b]{2}{*}{ Inoc. source ${ }^{a}$} & \multirow[b]{2}{*}{ Species tested } & \multirow[b]{2}{*}{ No. inoculated } & \multicolumn{3}{|c|}{ Plants testing positive with ${ }^{\mathrm{b}}$} & \multicolumn{2}{|c|}{ Plants symptomatic for ${ }^{\mathrm{C}}$} \\
\hline & & & & ELISA & Culture & PCR & PD & OLS \\
\hline A05/fastidiosa & Grape & Oleander & 15 & 0 & 0 & 0 & 0 & 0 \\
\hline A05/fastidiosa & Grape & Grape & 10 & 10 & 10 & 10 & 10 & 0 \\
\hline Riverside $3 /$ sandyi & Oleander & Oleander & 15 & 15 & 15 & 15 & 0 & 15 \\
\hline Riverside $3 /$ sandyi & Oleander & Grape & 10 & 0 & 0 & 0 & 0 & 0 \\
\hline $\mathrm{JM} 028 /$ sandyi $^{\mathrm{d}}$ & Jacaranda & Oleander & 15 & 15 & 15 & 15 & 0 & 15 \\
\hline $\mathrm{JM} 028 / s a n d y i^{\mathrm{d}}$ & Jacaranda & Grape & 10 & 0 & 0 & 0 & 0 & 0 \\
\hline MG038/sandyi ${ }^{\mathrm{d}}$ & Magnolia & Oleander & 15 & 15 & 15 & 15 & 0 & 15 \\
\hline MG038/sandyi ${ }^{\mathrm{d}}$ & Magnolia & Grape & 10 & 0 & 0 & 0 & 0 & 0 \\
\hline HEM034/sandyi ${ }^{\mathrm{d}}$ & Daylily & Oleander & 15 & 15 & 15 & 15 & 0 & 15 \\
\hline $\mathrm{HM} 034 /$ sandyi $^{\mathrm{d}}$ & Daylily & Grape & 10 & 0 & 0 & 0 & 0 & 0 \\
\hline Control & PBS buffer & Oleander & 15 & 0 & 0 & 0 & 0 & 0 \\
\hline Control & PBS buffer & Grape & 10 & 0 & 0 & 0 & 0 & 0 \\
\hline
\end{tabular}

${ }^{a}$ Inoculum source species; PBS = phosphate-buffered saline.

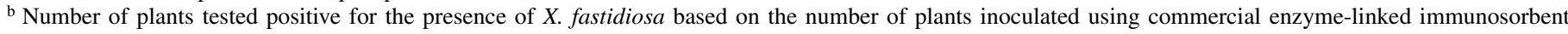
assay (ELISA) kits, media culturing methods, and RST31-33 primers for polymerase chain reaction (PCR) analysis (35).

c Number of plants exhibiting symptoms out of total of inoculated plants; PD = Pierce's disease and OLS $=$ oleander leaf scorch.

${ }^{\mathrm{d}}$ Putative members of the $X$. fastidiosa subsp. sandyi, identified in this work as sandyi for convenience.

this subspecies. The two strains isolated from western redbud fit into two different subspecies: $X$. fastidiosa subsp. multiplex and $X$. fastidiosa subsp. fastidiosa. This finding constitutes another example of two different genotypes of $X$. fastidiosa infecting a single host $(2,8)$.

In previous work, mulberry leaf scorch (MLS) strains formed a separate clade from $X$. fastidiosa subsp. fastidiosa when using RAPD analysis but were part of that subspecies when using $16 \mathrm{~S}$ rDNA sequence analysis (14). A separate report using $16 \mathrm{~S}-23 \mathrm{~S}$ rDNA ISR showed them as part of X. fastidiosa subsp. fastidiosa (37). Our data separated these strains from $X$. fastidiosa subsp. fastidiosa, X. fastidiosa subsp. mutiplex, and $X$. fastidiosa subsp. sandyi. In addition to the genetic evidence, it was demonstrated previously that a MLS strain could not infect oleander or grape (29). A subspecies name can be given to genetically determined clusters of strains or to groups of strains that show small but consistent phenotypic variation within a species (49); therefore, we hypothesize that the MLS strains could be recognized as a new subspecies, although additional molecular data and serological and phenotypic tests would be necessary to support this (45).

Last, we recognized that the strains isolated from jacaranda, magnolia, and daylily are members of $X$. fastidiosa subsp. sandyi. $X$. fastidiosa subsp. sandyi previously included strains isolated only from oleander (46). In greenhouse experiments, a strain from this subspecies multiplied, moved systemically, and caused wilting in Madagascar periwinkle (Catharanthus rosea) and leaf scorch in periwinkle (Vinca major), but it was unable to infect grape (Vitis vinifera), peach (Prunus persica), olive (O. europaea), blackberry (R. ursinus), or valley oak (Quercus lobata) (44). Until now, there has not been a report of oleander leaf scorch strains infecting other hosts in natural conditions. Our data showed that strains isolated from magnolia, jacaranda, and daylily were able to infect oleander but not grape plants, suggesting that this subspecies is not restricted to oleander. We intended to prove Koch's postulates using mechanical inoculations in these hosts but our efforts had been ineffective so far, maybe due to the hard woody nature of magnolia and jacaranda and to the very soft tissue of daylily, which has hampered mechanical inoculation, or other factors that we do not fully understand at this time. Oleander leaf scorch only reported only in 1999 (44), coinciding with the appearance of the GWSS in California. It is possible that this strain already was present in plants such as magnolia, jacaranda, and daylily, but only after the introduction of GWSS did these strains spread to oleander, where the damage was much more apparent.

The work presented here identifies $X$. fastidiosa strains associated with the rise of scorch and blights of landscape ornamentals in southern California and illustrates the diversity of these strains. Of these strains, many belonged to previously described subspecies and groups, although some strains, such as those from sweetgum, may belong to new groups. The work also showed that some hosts could be infected with more than one subspecies, as shown here for the almond and western redbud strains. The interaction between the insect vector, GWSS, and strains in such hosts could prove to be very interesting. Because multiple strains can coexist within the sharpshooter's mouthparts (15) and some plant hosts, there may be enhanced opportunities for recombination (46) among strains that would contribute to further strain diversity and allow for the infection of new hosts. Considerable genetic diversity exists among strains of $X$. fastidiosa $(2,7,8,14,25,37,45,46)$, but the relationship between genetic diversity and host specificity is still far from being fully understood. This work sheds some light on the diverse host range of several $X$. fastidiosa subspecies and groups. From a practical standpoint, understanding this host range and diversity is important for the rapid identification of new genotypes and strains and allows for improved diagnosis, management, and quarantine strategies that would help limit the spread and impact of this pathogen on economically important crops.

\section{ACKNOWLEDGMENTS}

Funding for this research was provided by the CDFA Pierce's Disease and Glassy-winged Sharpshooter Control Program, the University of California Institute for Mexico and the United States (UC-MEXUS), and the University of California Agricultural Experiment Station. R. Hernandez-Martinez had a scholarship from the Mexican Council for Science and Technology (CONACyT) and UC-MEXUS. This work is part of R. Hernandez-Martinez's Ph.D. dissertation at the University of California, Riverside. We thank A. Purcell and T. Wistrom for providing Xylella fastidiosa strains and $\mathrm{H}$. Azad for technical assistance and revision of the manuscript.

\section{LITERATURE CITED}

1. Albibi, R., Chen, J., Lamikanra, O., Banks, D., Jarret, R. L., and Smith, B. J. 1998. RAPD fingerprinting Xylella fastidiosa Pierce's disease strains isolated from a vineyard in north Florida. FEMS Microbiol. Lett. 165:347-352.

2. Almeida, R. P. P., and Purcell, A. H. 2003. Biological traits of Xylella fastidiosa strains from grapes and almonds. Appl. Environ. Microbiol. 69:7447-7452.

3. Barnard, E. L., Ash, E. C., Hopkins, D. L., and McGovern, R. J. 1998. Distribution of Xylella fastidiosa in oaks in Florida and its association with growth decline in Quercus laevis. Plant Dis. 82:569-572.

4. Blake, J. H. 1993. Distribution of Xylella fastidiosa in oak, maple, and sycamore in South Carolina. Plant Dis. 77:1262. 
5. Blua, M. J., and Morgan, D. J. W. 2003. Dispersion of Homalodisca coagulata (Hemiptera: Cicadellidae), a vector of Xylella fastidiosa, into vineyards in southern California. J. Econ. Entomol. 96:1369-1374.

6. Chang, C. J., and Walker, J. T. 1988. Bacterial leaf scorch of northern red oak: Isolation, cultivation, and pathogenicity of a xylem-limited bacterium. Plant Dis. 72:730-733.

7. Chen, J., Chang, C. J., Jarret, R. L., and Gawel, N. 1992. Genetic variation among Xylella fastidiosa strains. Phytopathology 82:973-977.

8. Chen, J., Groves, R., Civerolo, E. L., Viveros, A., Freeman, A., and Zheng, Y. 2005. Two Xylella fastidiosa genotypes associated with almond leaf scorch disease on the same location in California. Phytopathology 95:708-714.

9. Chen, J., Jarret, R. L., Qin, X., Hartung, J. S., Banks, D., Chang, C. J., and Hopkins, D. L. 2000. 16S rDNA sequence analysis of Xylella fastidiosa strains. Syst. Appl. Microbiol. 23:349-354.

10. Chen, J., Lamikanra, O., Chang, C. J., and Hopkins, D. L. 1995. Randomly amplified polymorphic DNA analysis of Xylella fastidiosa Pierce's disease and oak leaf scorch pathotypes. Appl. Environ. Microbiol. 61:1688-90.

11. Chen, J. C., Banks, D., Jarret, R. L., Chang, C. J., and Smith, B. J. 2000. Use of $16 \mathrm{~S}$ rDNA sequences as signature characters to identify Xylella fastidiosa. Curr. Microbiol. 40:29-33.

12. Chen, J. C., Banks, D., Jarret, R. L., and Jones, J. B. 2000. Evidence for conserved tRNA genes in the 16S-23S rDNA spacer sequence and two rrn operons of Xylella fastidiosa. Can. J. Microbiol. 46:1171-1175.

13. Chen, J. C., Civerolo, E. L., Jarret, R. L., Van Sluys, M. A., and de Oliveira, M. C. 2005. Genetic discovery in Xylella fastidiosa through sequence analysis of selected randomly amplified polymorphic DNAs. Curr. Microbiol. 50:78-83.

14. Chen, J. C., Hartung, J. S., Chang, C. J., and Vidaver, A. K. 2002. An evolutionary perspective of Pierce's disease of grapevine, citrus variegated chlorosis, and mulberry leaf scorch diseases. Curr. Microbiol. 45:423-428.

15. Costa, H. S., Guzman, A., Hernandez-Martinez, R., Gispert, C., and Cooksey, D. A. 2006. Detection and differentiation of Xylella fastidiosa strains acquired and retained by glassy-winged sharpshooters (Hemiptera: Cicadellidae) using a mixture of strain-specific primer sets. J. Econ. Entomol. 99:1058-1064.

16. Costa, H. S., Raetz, E., Pinckard, T. R., Gispert, C., Hernandez-Martinez, R., Dumenyo, C. K., and Cooksey., D. A. 2004. Plant hosts of Xylella fastidiosa in and near southern California vineyards. Plant Dis. 88:12551261.

17. Davis, M. J., Purcell, A. H., and Thomson, S. V. 1978. Pierce's disease of grapevines isolation of the causal bacterium. Science 199:75-77.

18. Davis, M. J., Purcell, A. H., and Thomson, S. V. 1980. Isolation media for the Pierce's disease bacterium. Phytopathology 70:425-429.

19. Davis, M. J., Raju, B. C., Brlansky, R. H., Lee, R. F., Timmer, L. W., Norris, R. C., and McCoy, R. E. 1983. Periwinkle wilt bacterium: axenic culture, pathogenicity, and relationships to other gram-negative, xyleminhabiting bacteria. Phytopathology 73:1510-1515.

20. De Lima, J. E. O., Miranda, V. S., Hartung, J. S., Brlansky, R. H., Coutinho, A., Roberto, S. R., and Carlos, E. F. 1998. Coffee leaf scorch bacterium: axenic culture, pathogenicity, and comparison with Xylella fastidiosa of citrus. Plant Dis. 82:94-97.

21. French, W. J. 1982. Reciprocal transmission of plum leaf scald and phony disease of peach. Phytopathology 72:452-453.

22. Goheen, A. C., Nyland, G., and Lowe, S. K. 1973. Association of a rickettsia-like organism with Pierce's disease of grapevines and alfalfa dwarf and heat therapy of the disease in grapevines. Phytopathology 63:341-345.

23. Gould, A. B., Wells, J. M., and Clarke, B. B. 1992. Distribution of oak leaf scorch in the Delaware Valley, New Jersey. (Abstr.) Phytopathology 82:1160.

24. Hearon, S. S., Sherald, J. L., and Kostka, S. J. 1980. Association of xylem limited bacteria with elm Ulmus americana, sycamore Platanus spp. and oak Quercus sp. leaf scorch. Can. J. Bot. 58:1986-1993.

25. Hendson, M., Purcell, A. H., Chen, D. Q., Smart, C., Guilhabert, M., and Kirkpatrick, B. 2001. Genetic diversity of Pierce's disease strains and other pathotypes of Xylella fastidiosa. Appl. Environ. Microbiol. 67:895903.

26. Hernandez-Martinez, R., Costa, H. S., Cooksey, D. A., and Wong, F. P. 2006. Sweet gum dieback in southern California caused by Xylella fastidiosa. (Abstr.) Phytopathology 96:S47.

27. Hernandez-Martinez, R., Costa, H. S., Dumenyo, C. K., and Cooksey, D. A. 2006. Differentiation of strains of Xylella fastidiosa infecting grape, almonds and oleander using a multiprimer PCR assay. Plant Dis. 90:13821388 .

28. Hernandez-Martinez, R., Dumenyo, C. K., Azad, H., Costa, H. S., Wong, F. P., and Cooksey, D. A. 2004. Phylogenetic analyses of Xylella fastidiosa strains isolated from ornamental hosts. (Abstr.) Phytopathology 94:S152.

29. Hernandez-Martinez, R., Pinckard, T. R., Costa, H. S., Cooksey, D. A., and Wong, F. P. 2006. Discovery and characterization of Xylella fastidiosa strains in southern California causing mulberry leaf scorch. Plant Dis. 90:1143-1149.

30. Hill, B. L., and Purcell, A. H. 1995. Multiplication and movement of Xylella fastidiosa within grapevine and four other plants. Phytopathology 85:1368-1372

31. Hopkins, D. L., and Purcell, A. H. 2002. Xylella fastidiosa: Cause of Pierce's disease of grapevine and other emergent diseases. Plant Dis. 86:1056-1066.

32. Huang, Q., and Sherald, J. 2004. Isolation and phylogenetic analysis of Xylella fastidiosa from its invasive alternative host, porcelain berry. Curr. Microbiol. 48:73-76.

33. Kostka, S. J., Sherald, J. L., Hearon, S. S., and Rissler, J. F. 1980 Serological Relatedness of elm and oak scorch associated bacteria to the Pierce's disease bacterium. Phytopathology 70:689-690.

34. Kostka, S. J., Sherald, J. L., and Tattar, T. A. 1982. Isolation of bacteria from three elm species and mulberry exhibiting leaf scorch. (Abstr.) Phytopathology 72:936.

35. Kumar, S., Tamura K., and Nei, M. 2004. MEGA3: Integrated software for molecular evolutionary genetics analysis and sequence alignment. Brief. Bioinf. 5:150-163.

36. McGovern, R. J., and Hopkins, D. L. 1994. Association of Xylella fastidiosa with leaf scorch and decline of live oak in Florida. Plant Dis. 78:924.

37. Mehta, A., and Rosato, Y. B. 2001. Phylogenetic relationships of Xylella fastidiosa strains from different hosts, based on 16S rDNA and 16S-23S intergenic spacer sequences. Int. J. Syst. Evol. Microbiol. 51:311-318.

38. Meyer, M., Kocsis, L., and Walker, A. 2002. Transmission of Pierce's disease by chip-budding and bench-grafting. Am. J. Enol. Viticult. 53:248A.

39. Minsavage, G. V., Thompson, C. M., Hopkins, D. L., Leite, R. M. V. B. C., and Stall, R. E. 1994. Development of a polymerase chain reaction protocol for detection of Xylella fastidiosa in plant tissue. Phytopathology $84: 456-461$

40. Mircetich, S. M., Lowe, S. K., Moller, W. J., and Nyland, G. 1976. Etiology of almond leaf scorch disease and transmission of the causal agent. Phytopathology 66:17-24.

41. Page, R. D. M. 1996. TREEVIEW: An application to display phylogenetic trees on personal computers. Comput. Appl. Biosci. 12:357-358.

42. Purcell, A. H., Finlay, A. H., and McLean, D. L. 1979. Pierce's disease bacterium mechanism of transmission by leafhopper vectors. Science 206:839-841

43. Purcell, A. H., and Saunders, S. R. 1999. Fate of Pierce's disease strains of Xylella fastidiosa in common riparian plants in California. Plant Dis. 83:825-830.

44. Purcell, A. H., Saunders, S. R., Hendson, M., Grebus, M. E., and Henry, M. J. 1999. Causal role of Xylella fastidiosa in oleander leaf scorch disease. Phytopathology 89:53-58.

45. Schaad, N. W., Postnikova, E., Lacy, G., Fatmi, M. B., and Chang, C.-J. 2004. Xylella fastidiosa subspecies: X. fastidiosa subsp. fastidiosa, subsp. multiplex subsp. nov., and X. fastidiosa subsp. pauca. Syst. Appl. Microbiol. 27:290-300.

46. Schuenzel, E. L., Scally, M., Southammer, R., and Nunney, L. 2005. A multigene phylogenetic study of clonal diversity and divergence in North American strains of the plant pathogen Xylella fastidiosa. Appl. Environ. Microbiol. 71:3832-3839.

47. Sherald, J., Hearon, S., Kostka, S., and Morgan, D. 1982. Pathogenicity of a Pierce's disease (PD)-like bacterium cultured from leaf scorch affected sycamores. (Abstr.) Phytopathology 72:710.

48. Sherald, J. L., Wells, J. M., Hurtt, S. S., and Kostka, S. J. 1987. Association of fastidious xylem-inhabiting bacteria with leaf scorch in red maple. Plant Dis. 71:930-933.

49. Staley, J., and Krieg, N. R. 1984. Bacterial classification I. Classification of procaryotic organisms: An overwiev. Pages 1-4 in: Bergey's Manual of Systematic Bacteriology, Vol. 1. N. R. Krieg and J. G. Holt, eds. Williams and Wilkins, Baltimore.

50. Swofford, D. L. 2002. Phylogenetic Analysis Using Parsimony (and Other Methods). Sinauer Associates, Sunderland, MA.

51. Thompson, J. D., Gibson, T. J., Plewniak, F., Jeanmougin, F., and Higgins, D. G. 1997. The CLUSTAL_X windows interface: Flexible strategies for multiple sequence alignment aided by quality analysis tools. Nucleic Acids Res. 25:4876-4882

52. Turner, W. P., and Herschel, N. 1959. Life histories and behavior of five insect vectors of phony peach disease. U. S. Dep. Agric. Tech. Bull. 1188.

53. Wells, J. M., Raju, B. C., Hung, H. Y., Weisburg, W. G., Mandelco-Paul, L., and Brenner, D. J. 1987. Xylella fastidiosa new-genus new-species Gram-negative xylem-limited fastidious plant bacteria related to Xanthomonas spp. Int. J. Syst. Bacteriol. 37:136-143.

54. Wells, J. M., Raju, B. C., Thompson, J. M., and Lowe, S. K. 1981. Etiology of phony peach and plum leaf scald diseases. Phytopathology $71: 1156-1161$ 